\title{
EFFECT OF A NEAR FAULT ON THE SEISMIC RESPONSE OF A BASE-ISOLATED STRUCTURE WITH A SOFT STOREY
}

\author{
B. ATHAMNIA ${ }^{*}$, A. OUNIS ${ }^{2}$, M. ABDEDDAIM ${ }^{3}$
}

\begin{abstract}
This study focuses on the soft-storey behavior of $R C$ structures with lead core rubber bearing ( $L R B)$ isolation systems under near and far-fault motions. Under near-fault ground motions, seismic isolation devices might perform poorly because of large isolator displacements caused by large velocity and displacement pulses associated with such strong motions. In this study, four different structural models have been designed to study the effect of soft-storey behavior under near-fault and far-fault motions. The seismic analysis for isolated reinforced concrete buildings is carried out using a nonlinear time history analysis method. Inter-story drifts, absolute acceleration, displacement, base shear forces, hysteretic loops and the distribution of plastic hinges are examined as a result of the analysis. These results show that the performance of a base isolated $R C$ structure is more affected by increasing the height of a story under nearfault motion than under far-fault motion.
\end{abstract}

Address

1 LARGHYDE Laboratory, Department of Civil Engineering, Faculty of Sciences and Technology, Tebessa University, Algeria, 12000 Algeria, Email: athamnia.bahim@gmail.com

2 Professor, LARGHYDE Laboratory, Department of Civil Engineering and Hydraulics, Faculty of Sciences and Technology, Mohamed Khider University, Algeria, 07000 Algeria, Email: a.ounis@univ-biskra.dz

3 LARGHYDE Laboratory, Department of Civil Engineering and Hydraulics, Faculty of Sciences and Technology, Mohamed Khider University, Algeria

* Corresponding author: abdeddaim_mms@yahoo.fr

\section{Key words}

- Soft story,

- Near-fault,

- Far-fault,

- Nonlinear analysis,

- Damage,

- Effective Analyses.

\section{INTRODUCTION}

The concept of a soft first story was first proposed by Fintel and Khan (Fintel \& Khan, 1969). Researchers had pointed out some aspects of a flexible first story in the late 1920s and1930s (Green, 1935; Jacobsen, 1938; Martel, 1929), but its practical significance did not become evident until observations of damage in multistory buildings during earthquakes in the 1960s. A soft-story, which is a weak-story, is defined as a story in a building that has substantially less resistance, stiffness, or inadequate ductility (energy absorption capacity) to resist earthquake-induced building stresses. Soft-story buildings are characterized by having a story which has a lot of open space. Parking garages, for example, are often soft stories, as are large retail spaces or floors with a lot of openings (Hejazi et al., 2011). The base isolation technique was developed as an attempt to reduce the effects of earthquakes on buildings and their structural elements during seismic events, and it became one of the most effective methods for dealing with a wide range of problems of structures under seismic action. (Dadkhah \& Noruzvand, 2017; Naeim \& Kelly, 1999; R. Skinner, W. Robinson, \& G. McVerry, 1993; R. I. Skinner, W. H. Robinson, \& G. H. McVerry, 1993). In recent decades, base isolation has become one of the most accepted techniques for the seismic protection of buildings (Higashino \& Okamoto, 2006). High damping rubber bearing (HDRB), laminated rubber bearing, lead-rubber bearing (LRB), and the friction pendulum system (FPS) are the most often employed isolation systems in building structures (Heaton, Hall, Wald, \& Halling, 1995). The most applicable isolation system, which is used in New Zealand, Japan and the United States, is the lead-rubber bearing (LRB) system. The LRB contains many rubber layers and steel plates with holes, which have one or more lead plugs inserted in them. The shear deformation of the lead core provides a bi-linear response and primary rigidity against seismic 
excitations (Jankowski, Wilde, \& Fujino, 2000; Kelly, 2001; Naeim \& Kelly, 1999). The LRB isolator is able to withstand vertical loading(Nittmannová \& Magura, 2016). Due to the horizontal flexibility of LRB, it has a restorative force. The LRB isolation system with a lead plug also provides essential hysteretic damping (Providakis, 2008). Studies have shown that ground motion characteristics have a significant effect on the performance of LRB bearings (Hameed, Koo, Dai Do, \& Jeong, 2008). According to certain seismology researchers, base isolated buildings are damaged by near-fault ground motion more often than far-field motion, because of the pulse-like ground motion at near-fault sites (Hall, Heaton, Halling, \& Wald, 1995; Heaton et al., 1995). Near-fault ground motions have various characteristics such as extensive peak ground acceleration, a large vertical ground motion, an intense long-period velocity pulse wave, and forward rupture directivity. The forward rupture directivity effect is a velocity pulse at the beginning of near-fault records (Bray \& Rodriguez-Marek, 2004; Tothong, Cornell, \& Baker, 2007). Several important studies have been carried out concerning base-isolated structures subjected to soft-story effects and near-fault and far-field ground motions. In many of the examinations, the LRB bearings are used as an isolation system. Trombetti (Gupta \& Santhi, 2015) focused on the "shock-absorbing soft storey concept". Their purpose was to design a first story isolated building capable of satisfying selected seismic performance objectives. The performance of the building under multiple earthquake design levels was finally verified through a nonlinear time history analysis, the results of which confirmed the effectiveness of the proposed approach. Providakis (Providakis, 2008) investigated the seismic behavior of steel-concrete composite structures with LRB base isolation under near-fault ground motions. He indicated that a base-isolation system not only mitigates the base shear of a building subjected to near-fault earthquake excitations, but also increases the drift of the first floor. (Jangid, 2007) presented an analysis of the seismic response of an isolated building under near-fault ground motions that used LRB. He used a bi-linear model to determine the force-deformation behavior of the LRB; then he found that low bearing yield strength values intensively increase displacements under near-fault motions. In addition, he stated that the high-level displacement of LRB isolators under near-fault motions cause instability in an isolation system. He pointed out that the reports related to the efficiency of the LRB subjected to near-fault motions are not very favorable. Sharbatdar et al. (Sharbatdar, Vaez, Amiri, \& Naderpour, 2011) studied the seismic response of structures using an isolation system with both FPS and LRB isolators under near-fault motions. They found that the results of the analysis for near and far-fault ground motions are considerably different from each other. They used the records of near-fault motions with strong velocity and displacement pulses for relatively long periods to differentiate them from far-field motions and took into account the particular aspects of near-fault motions to estimate the seismic responses of a structure with an isolation system. Their examination showed that the large displacement and velocity pulses of near-fault motions can severely affect the seismic responses of base-isolated structures.

The objective of this paper is to examine the behavior of a 12-story base-isolated reinforced-concrete building, with a ground story with a height of 4.5, 4.0, 3.5 and $3.0 \mathrm{~m}$ height subjected to near-fault ground motions. In order to facilitate an assessment of the effects of the near-fault records on the structural response, a set of near-fault ground motions having forward directivity and a fling step were assembled. These records are used in nonlinear time history analyses, and their results are compared to the response of buildings to far-fault ground motions. Also, in order to achieve this objective, simple sinusoidal waveforms that adequately describe the nature of pulse-like motions are utilized as a seismic input.

\section{CHARACTERISTICS OF NEAR-FAULT GROUND MOTIONS}

A near-fault of an earthquake can be defined as an area in the close vicinity of the fault's rupture surface. Besides strong shaking, the characteristics of near-fault ground motions are linked to the fault's geometry and the orientation of the traveling seismic waves. Vertical strike-slip faults can produce a directivity effect, and dipslip faults can produce directivity effects as well as hanging wall effects. Hanging wall effects are felt on the hanging wall of a fault (the earth above a vertically dipping fault), and are due to the proximity of much of the fault to hanging wall sites. Directivity effects can be classified as forward, reverse, or neutral. Fig. 1 portrays the three zones of directivity, with the star representing the epicenter and the black line indicating the fault. The rupture's directivity pulse is oriented in the strike-normal direction, and the static ground displacement (flingstep) is oriented parallel to the fault strike. The fling step is a result of the evolution of a residual ground displacement due to a tectonic deformation associated with the rupture mechanism. This phenomenon is characterized by a large unidirectional amplitude velocity pulse and a monotonic step in the displacement time history. It arises in strikeslip faults in a parallel direction of the strike or in the strike-normal direction for dip-slip faults. In general, a permanent displacement is considered to be a pseudo-static deformation, and its frequency is smaller than that of a forward directivity pulse (Mortezaei, Ronagh, \& Kheyroddin, 2010).

\section{LEAD RUBBER BEARING ISOLATION SYSTEMS}

The LRB system was invented in New Zealand in 1975 and developed as an elastomeric-based system. Later, it was widely used in developed countries such as Japan and the USA. The working principle of this system is similar to the laminated rubber bearing system. The systems differ because a cylindrical lead core is placed in the middle of the LRB system to provide additional rigidity to the system(Ounis \& Ounis, 2013) (Fig. 2). The lead core increases the energy absorption capacity of the system; therefore, the lateral stiffness is potentially increased against strong ground motions. Consequently, the main aim of the lead addition is to increase both the stiffness at relatively low horizontal force levels and the energy dissipation capacity. The characteristics of the lead material have been considered in the production of LRB systems. In general, lead has a low yield point when its shear stress reaches $10 \mathrm{MPa}$ and it exhibits elasto-plastic behavior. Lead is also resistant to repeated loads and can renew itself over time following deformation. The system has a high initial stiffness against minor horizontal forces caused by either wind or mild earthquakes that may affect the structure (Robinson, 1982a, 1982b; Skinner, Kelly, \& Heine, 1974). The most significant disadvantage of this system is that when the system is exposed to strong ground motion, it is impossible to determine whether damage to the lead core in the center has occurred. In addition, this system does not have the capability to restore to zero position after strong earthquake.

\section{MODELING OF BUILDING STRUCTURES}

In this study a 12-story RC building was modeled to study the effect of a soft story on the dynamic behavior of the building under near and far-fault motion. The soft-story was supposed to be implemented on the bottom floor of a base-isolated building. A reinforced concrete building of 12 stories with a rectangular plan of $12 \times 24 \mathrm{~m}$ was considered; it has four bays in a longitudinal direction and two bays with a transverse directional spacing of $6 \mathrm{~m}$. The sections of the 
beams are $30 \times 60 \mathrm{~cm}^{2}$; the sections of the columns are $90 \times 90 \mathrm{~cm}^{2}$; and the normal floor height is $3 \mathrm{~m}$ with $18 \mathrm{~cm}$ thick to be solid slabs. We considered the different values of the soft bottom floor's height (H) 3.0, 3.5, 4.0 and 4.5, (Fig.3).

According to the ACI 318 (2002) for concrete, the material properties are considered to have a compressive strength equal to 24.5 $\mathrm{MPa}$, a Poisson ratio of 0.2 and a Young's modulus of $23 \mathrm{MPa}$. The longitudinal reinforcement of the transverse sections is $3 \%$ with a yield stress of $338 \mathrm{MPa}$, a Poisson ratio of 0.3, and a Young's modulus of 2E5 MPa for all the columns and beams. The building contains 15 lead rubber bearings below each column. On the other hand, nonlinear models using NONLINK elements are used (CSI 2003); they require the input of the three basic parameters for the bilinear modeling of the bearings: initial stiffness, $K_{1}$, yield strength, $F_{y}$, and post-yield-to-initial-stiffness ratio $K_{2} / K_{1}$. The bearings are designed for an isolation period of $T_{b}=2.5 \mathrm{sec}$, which leads to an effective horizontal stiffness of $K_{\text {eff }}=1047.26 \mathrm{kN} / \mathrm{m}$ for identical bearings. It is to be noted that the SAP2000 program uses this stiffness value in its modal analysis of base isolation models. The design displacement and other calculations for the bearings in this study are per ASCE710. Assuming that the building studied is located near an active fault, a relatively high value is used for $S_{D 1}=0.33$. It is worth noting that the assumed values for the geometric and material properties of the bearings (shape factor: $S=0.20$; thickness of steel plates: $t_{s}=2 \mathrm{~mm}$; effective damping: $\beta_{b}=2 \%$; shear modulus: $G=0.35 \mathrm{MPa}$; bulk modulus: $K=2000 \mathrm{Mpa}$; and yield stress of the lead: $\tau_{b}=6.9 \mathrm{MPa}$ ), are all typical values quoted in the literature (Naeim \& Kelly, 1999). Consequently, the bilinear properties of the bearings have been determined to be $K_{1}=7182.56 \mathrm{kN} / \mathrm{m}$ and $F_{y}=75.80 \mathrm{kN}$ by assuming $K_{2} / K_{1}=$ 0.1 , which is also typical.

\section{METHODOLOGY OF THE NONLINEAR TIME HISTORY ANALYSIS}

SAP2000 commercial software (Habibullah \& Wilson, 2005) was utilized to perform the nonlinear dynamic analyses of the base-isolated RC building frame. The dynamic responses have been evaluated by the nonlinear time history analysis method, whereby base-isolated buildings are compared with each other under near-fault and far-fault motions. The 12-story building is considered using the time history analysis. The nonlinearity of the beam and column members was modeled by considering plastic hinges at both ends of the elements. The plastic hinges of the uniaxial bending moments for the beams and the axial loads and uniaxial bending moments were assigned to the columns in accordance with ATC-40 (FEMA, 1997) and FEMA-273 (Comartin, Niewiarowski, Freeman, \& Turner, 2000) documents. Damping was considered in the case of the mass and proportional stiffness damping with $5 \%$ damping in the first and second modes. The Newmark method of step-by-step integration, with $\gamma=0.5$ and $\beta=0.25$, was selected to perform the nonlinear direct integration time-history analysis.

\section{GROUND MOTION DATABASE}

The ground motion database compiled for the nonlinear time history analyses constitutes a representative number of far-fault and near-fault ground motions from a variety of tectonic environments.

A total of 9 records were selected to cover a large range of frequency contents, durations, and amplitudes. Near-fault records were chosen so as to be able to consider the presence of both forward-directivity and fling-step effects. Hence the assembled database can be investigated in three sub-data sets. Pertinent information on the ground motion data sets, including the faulting mechanism, the site classification of the stations and peak ground acceleration (PGA), the peak ground velocity (PGV), and the peak ground displacement (PGD) of the records are presented in Table 2. The spectra of the scaled ground motions together with the design spectrum are presented in Fig.4.

From the preliminary information generated through the evaluation of the base isolated building discussed above, it is clear that the building's response differs with respect to far-fault and near-fault ground motions. However, in order to achieve a more coherent understanding of the effects of near-fault records, a systematic study was conducted on the same structure using simple pulse motions that reasonably represent forward-directivity and fling effects.

In several academic research papers, simplified pulse-type ground motions were defined with forward motion only and with forward and backward motions using linear variables for velocity and acceleration (Hall et al., 1995; Sasani, 2006). Alavi and Krawinkler used linear variable simplified pulses for velocity and acceleration, but they modified triangle-shaped velocity pulses with parabolic curves in order to study the effect of the rise time on the response parameters (Alavi \& Krawinkler, 2001). Simplified pulse-type ground motions were modeled with trigonometric variables according to several academic papers (Makris, 1997; Makris \& Chang, 2000; Rodriguez-Marek \& Bray, 2006). Makris (Makris, 1997) proposed pulsetype A with a forward motion and pulse-type B with forward and back motions with simple trigonometric functions called cycloidal fronts. Equations of the A and B type motions are given in Eqs (1-3) and Eqs (4-6), respectively. In these equations, $\ddot{x}_{g}(t), \dot{x}_{g}(t), x_{g}(t), \omega_{p}, V_{p}(t)$, $t$ and $T_{p}$ describe the ground acceleration, ground velocity, ground displacement, pulse frequency, peak ground velocity (PGV), and the time and pulse periods, respectively.

$$
\begin{array}{ll}
\ddot{x}_{g}(t)=\omega_{p} \frac{V_{p}}{2} \sin \left(\omega_{p} t\right) & 0 \leq \mathrm{t} \leq \mathrm{T}_{\mathrm{p}} \\
\dot{x}_{g}(t)=\frac{V_{p}}{2}-\frac{V_{p}}{2} \cos \left(\omega_{p} t\right) & 0 \leq \mathrm{t} \leq \mathrm{T}_{\mathrm{p}} \\
x_{g}(t)=\frac{V_{p}}{2} t-\frac{V_{p}}{2 \omega_{p}} \sin \left(\omega_{p} t\right) & 0 \leq \mathrm{t} \leq \mathrm{T}_{\mathrm{p}} \\
\ddot{x}_{g}(t)=\omega_{p} V_{p} \cos \left(\omega_{p} t\right) & 0 \leq \mathrm{t} \leq \mathrm{T}_{\mathrm{p}} \\
\dot{x}_{g}(t)=V_{p} \sin \left(\omega_{p} t\right) & 0 \leq \mathrm{t} \leq \mathrm{T}_{\mathrm{p}} \\
x_{g}(t)=\frac{V_{p}}{\omega_{p}}-\frac{V_{p}}{\omega_{p}} \cos \left(\omega_{p} t\right) &
\end{array}
$$

The acceleration, velocity, and displacement ( 5 percent damped) of the elastic response spectra of the pulse models are shown in (Fig.5), where the spectral ordinates are normalized by their corresponding peak time-history values (i.e., PGA, PGV, and PGD).

\section{SEISMIC RESPONSE EVALUATION OF BUILDINGS}

A total of 9 nonlinear time-history (NTH) analyses were conducted on the base isolated building. The inter-story drift ratio (IDR), which is defined as the relative displacement between two consecutive story levels, was used as the primary measure of the seismic demands. Additional demand measures, such as component and story ductility, were also investigated. In general, there was a reasonable 
correlation between the inter-story drift demands and the component/ story-level ductility demands; hence these results are not included here. The peak inter-story drift profiles obtained from the NTH analyses of the buildings were subjected to three sets of ground motions (i.e., far-fault motions, near-fault motions with forward directivity, and near-fault motions with a fling step).

The inter-story drift ratios of the base-isolated building are presented in (Fig.6). The inter-story drift ratios of the building (i.e., the height of the first story of the building varied between 3, 3.5, 4 and $4.5 \mathrm{~m}$ ) remained within a small range in far-fault motion, and those values are less than those for a building subjected to near-fault motion. In addition, the effect of increasing the height (soft-story) of the first story produced maximum inter-story drift demands in the nearfault motion with a fling greater than the forward directivity and farfault motion, respectively. The maximum drift of $\mathrm{H}=4.50 \mathrm{~m}$ was concentrated on the first story of the building. The largest demand was caused by the TCU068-N record, which produced a 0.0120 inter-story drift. Otherwise, the maximum values for the other heights $(\mathrm{H}=3$, 3.5 , and $4 \mathrm{~m}$ ) were generally determined at the second story for all the records. For the near-fault motion with forward directivity, the largest demand was caused by the SCS142 record for all the ground-story heights. For the far-fault motion, the largest demand was caused by the CFH090 record for all the ground-story heights.

The displacements of the first story are shown in (Fig.7). The displacement at the first level increased as the ground story heights increased. Accordingly, the displacement for the TCU068 record showed a reduction of $4.94 \%$ for the ground story height of $\mathrm{H}=3 \mathrm{~m}$, which is less than the ground story height of $\mathrm{H}=4.50 \mathrm{~m}$. Moreover, the displacement for the SCS142 and CFH090 records showed a reduction of $3.08 \%$ and $1.76 \%$ respectively. The displacement of the ground story with a height of $\mathrm{H}=3 \mathrm{~m}$ is less than the ground story with a height of $\mathrm{H}=4.50 \mathrm{~m}$.

In the base-isolated structure under the near-fault and far-fault motions, the story's acceleration generally increased toward the upper story as is shown in Fig. 8. Accordingly, the maximum acceleration values for the base storeys and the top storey were obtained from the KJM00, the TCU068 and the CFH090 records for $\mathrm{H}=3 \mathrm{~m}$, respectively. However, the minimum acceleration values for the mid-storeys were obtained from the SKR090, the LEX090 and the BLF206 records for $\mathrm{H}=4.5 \mathrm{~m}$, respectively. Moreover, at the level of the LRB base isolation system, the maximum acceleration was obtained from the KJM00 record.

To represent the effect of the near-fault motion, an equivalent pulse is used here to study the variations in the base shear forces with the time and hysteretic loops as shown in (Figs. 9 and 10). For the KJM00, SKR090 and CFH090 records, in the near-fault and far-fault motions, increasing the ground story's height decreased the stiffness of the structure, thereby causing reductions in the base shear forces. The reductions in base shears in the near-fault and far-fault motions are very small. Moreover, this reduction in the near-fault motion is less than in the far-fault motion. For example, the reduction value between $\mathrm{H}=4.5$ and $3 \mathrm{~m}$ for the SKR090, KJM00 and CFH090 records is $0.32 \%, 0.55 \%$ and 1.22 , respectively. This reduction value for the equivalent pulses for the SKR090 and KJM00 records is $0.37 \%$ and $5 \%$, respectively.

The dissipation energy is represented by the hysteretic loop of the LRB base isolation system. For the near-fault motion, the capacity of the LRB base isolation system remained within a small range when increasing the ground story's height. On the other hand, the capacity of the LRB base isolation system in the far-fault motion is less than in the near-fault motion. The maximum dissipation energy was obtained from the KJM00 record.

The plastic hinge distributions that were obtained from the KJM00, SKR090 and CFH090 records are shown in (Fig. 11). The near-fault and far-fault motions caused little damage in the base-isolated structure for the whole ground storey. However, the distribution of the plastic hinges for the KJM00 record is more than for the SKR090 and CFH090 records, respectively. In addition, the plastic hinges were formed in the beams for all the ground storey from the near-fault and far-fault motions. On the other hand, the plastic hinges in the near and far-fault motions occurred at the level of the base isolation and at the first and second storeys, where the height of the ground soft storey was 4.5 and $4 \mathrm{~m}$. Therefore, the ground storey heights of $4,3.5$ and $3 \mathrm{~m}$ caused damage at the level of the LRB base isolation system more than the other stories from the near-fault motion.

\section{CONCLUSION}

In this study, nonlinear dynamic analyses were applied to different ground-storey heights and acceleration records for a 12-storey LRB base-isolated RC structure. From the analysis, the effect of the soft-story behavior on the inter-storey drift, storey acceleration, displacements, and shear forces was determined.

- The major reasons for damage in the structure during earthquakes are the response of the large inter-storey drift and high-storey accelerations. However, for LRB base-isolated structures, the inter storey demands and high storey accelerations are damped significantly more in the far-fault motion than in the near-fault motion. The maximum inter-story demand was obtained in the near-fault motion with fling steps. On the other hand, the maximum high-storey accelerations were produced in the near-fault motion with forward directivity.

- The base shear forces and the dissipation energy significantly decreased in the LRB base isolation system in the far-fault motion more than in the near-fault motion with and without an equivalent pulse.

- The near-fault and far-fault motions caused little damage in the base-isolated structures for the whole ground storey, while plastic hinges only occurred in the beams. Moreover, in the far-fault motion the plastic hinges were generally negligible.

- The soft-storey behavior does not have any significant effect on the LRB base-isolated structures when considering the inter-storey damage, the high-storey acceleration, the base shear force, and the plastic hinges in the far-fault motion. However, soft-storey behavior can adversely affect the safety of the structure for base-isolated structures when considering the inter-storey damage and high-storey acceleration.

- An LRB isolation system increases the safety of a structure in a far-fault motion. However, the LRB isolation system decreases the safety of the structure in a near-fault motion with a soft-storey effect. In order to perform better, other control systems such as hybrid control or active control can be coupled with an LRB isolation system for a hybrid control which will reduce the seismic demands. 


\section{REFERENCES}

Alavi, B., \& Krawinkler, H. (2001). Effects of near-fault ground motions on frame structures: John A. Blume Earthquake Engineering Center Stanford.

Bray, J. D., \& Rodriguez-Marek, A. (2004). Characterization of forward-directivity ground motions in the near-fault region. Soil dynamics and earthquake engineering, 24(11), 815-828.

Comartin, C. D., Niewiarowski, R. W., Freeman, S. A., \& Turner, F. M. (2000). Seismic evaluation and retrofit of concrete buildings: a practical overview of the ATC 40 Document. Earthquake Spectra, 16(1), 241-261.

Dadkhah, H., \& Noruzvand, M. (2017). Optimal Response-Related Weighting Matrices to Control Semi-Active Base Isolation Systems. Slovak Journal of Civil Engineering, 25(2), 24-32.

Fema, F. (1997). FEMA 273-274: NEHRP Guidelines for the Seismic Rehabilitation of Buildings and Commentary: FEMA.

Fintel, M., \& Khan, F. R. (1969). Shock-absorbing soft story concept for multistory earthquake structures. Paper presented at the Journal Proceedings.

Green, N. B. (1935). Flexible first-story construction for earthquake resistance. Paper presented at the Proceedings of the American Society of Civil Engineers.

Gupta, S., \& Santhi, D. M. H. (2015). Dynamic Analysis of Soft Storey Frame with Isolators. IJMTST, ISSN, 2455-3778.

Habibullah, A., \& Wilson, E. (2005). SAP 2000" Static and Dynamic Finite Element Analysis of Structures. Computers and Structures Inc. Berkeley, California.

Hall, J. F., Heaton, T. H., Halling, M. W., \& Wald, D. J. (1995). Near-source ground motion and its effects on flexible buildings. Earthquake Spectra, 11(4), 569-605.

Hameed, A., Koo, M.-S., Dai Do, T., \& Jeong, J.-H. (2008). Effect of lead rubber bearing characteristics on the response of seismic-isolated bridges. KSCE Journal of Civil Engineering, 12(3), 187-196.

Heaton, T. H., Hall, J. F., Wald, D. J., \& Halling, M. W. (1995). Response of high-rise and base-isolated buildings to a hypothetical Mw 7.0 blind thrust earthquake. Science, 267(5195), 206.

Hejazi, F., Jilani, S., Noorzaei, J., Chieng, C., Jaafar, M., \& Ali, A. A. (2011). Effect of soft story on structural response of high rise buildings. Paper presented at the IOP Conference Series: Materials Science and Engineering.

Higashino, M., \& Okamoto, S. (2006). Response control and seismic isolation of buildings: Routledge.

Jacobsen, L. S. (1938). Effects of a flexible first story in a building located on vibrating ground. S. Timoshenko 60th Anniversary Volume, 93-103.

Jangid, R. (2007). Optimum lead-rubber isolation bearings for near-fault motions. Engineering structures, 29(10), 2503-2513.

Jankowski, R., Wilde, K., \& Fujino, Y. (2000). Reduction of pounding effects in elevated bridges during earthquakes. Earthquake engineering \& structural dynamics, 29(2), 195-212.

Kelly, T. (2001). Base isolation of structures: Design guidelines. Auckland: Holmes Consulting Group Ltd.
Makris, N. (1997). Rigidity-plasticity-viscosity: Can electrorheological dampers protect base-isolated structures from near-source ground motions? Earthquake Engineering and Structural Dynamics, 26(5), 571-592.

Makris, N., \& Chang, S.-P. (2000). Effect of viscous, viscoplastic and friction damping on the response of seismic isolated structures. Earthquake engineering \& structural dynamics, 29(1), 85-107.

Martel, R. (1929). The effects of earthquakes on buildings with a flexible first story. Bulletin of the Seismological Society of America, 19(3), 167-178

Mortezaei, A., Ronagh, H. R., \& Kheyroddin, A. (2010). Seismic evaluation of FRP strengthened $R C$ buildings subjected to nearfault ground motions having fling step. Composite Structures, 92(5), 1200-1211.

Naeim, F., \& Kelly, J. M. (1999). Design of seismic isolated structures: from theory to practice: John Wiley \& Sons.

Nittmannová, L., \& Magura, M. (2016). Interaction of Reinforced Elastomeric Bearings in Bridge Construction. Slovak Journal of Civil Engineering, 24(1), 34-40.

Ounis, H. M., \& Ounis, A. (2013). Parameters Influencing the Response of a Base-Isolated Building. Slovak Journal of Civil Engineering, 21(3), 31-42.

Providakis, C. (2008). Pushover analysis of base-isolated steel-concrete composite structures under near-fault excitations. Soil dynamics and earthquake engineering, 28(4), 293-304.

Robinson, W. H. (1982a). Lead-rubber hysteretic bearings suitable for protecting structures during earthquakes. Earthquake engineering \& structural dynamics, 10(4), 593-604.

Robinson, W. H. (1982b). Lead-rubber hysteretic bearings suitable for protecting structures during earthquakes Earthquake engineering \& structural dynamics (Vol. 10, pp. 593-604).

Rodriguez-Marek, A., \& Bray, J. D. (2006). Seismic site response for near-fault forward directivity ground motions. Journal of Geotechnical and Geoenvironmental Engineering, 132(12), 1611-1620.

Sasani, M. (2006). New measure for severity of near-source seismic ground motion. Journal of Structural Engineering, 132(12), 19972005.

Sharbatdar, M., Vaez, S. H., Amiri, G. G., \& Naderpour, H. (2011). Seismic response of base-isolated structures with LRB and FPS under near fault ground motions. Procedia Engineering, $14,3245-3251$

Skinner, R., Kelly, J., \& Heine, A. (1974). Hysteretic dampers for earthquake-resistant structures. Earthquake engineering \& structural dynamics, 3(3), 287-296.

Skinner, R., Robinson, W., \& McVerry, G. (1993). An introduction to seismic isolationJohn Wiley and Sons. New York.

Skinner, R. I., Robinson, W. H., \& McVerry, G. H. (1993). An introduction to seismic isolation: John Wiley \& Sons.

Tothong, P., Cornell, C. A., \& Baker, J. (2007). Explicit directivity-pulse inclusion in probabilistic seismic hazard analysis. Earthquake Spectra, 23(4), 867-891. 

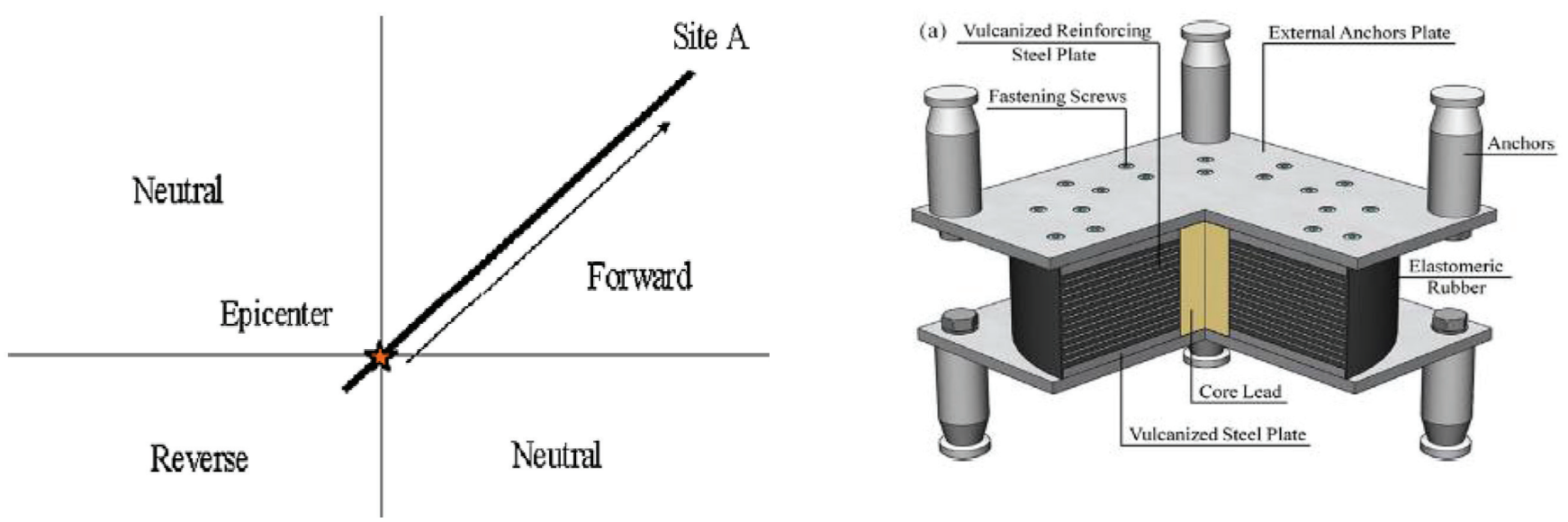

Fig. 1. Zones of directivity

Fig.2. Lead rubber bearing (LRB)

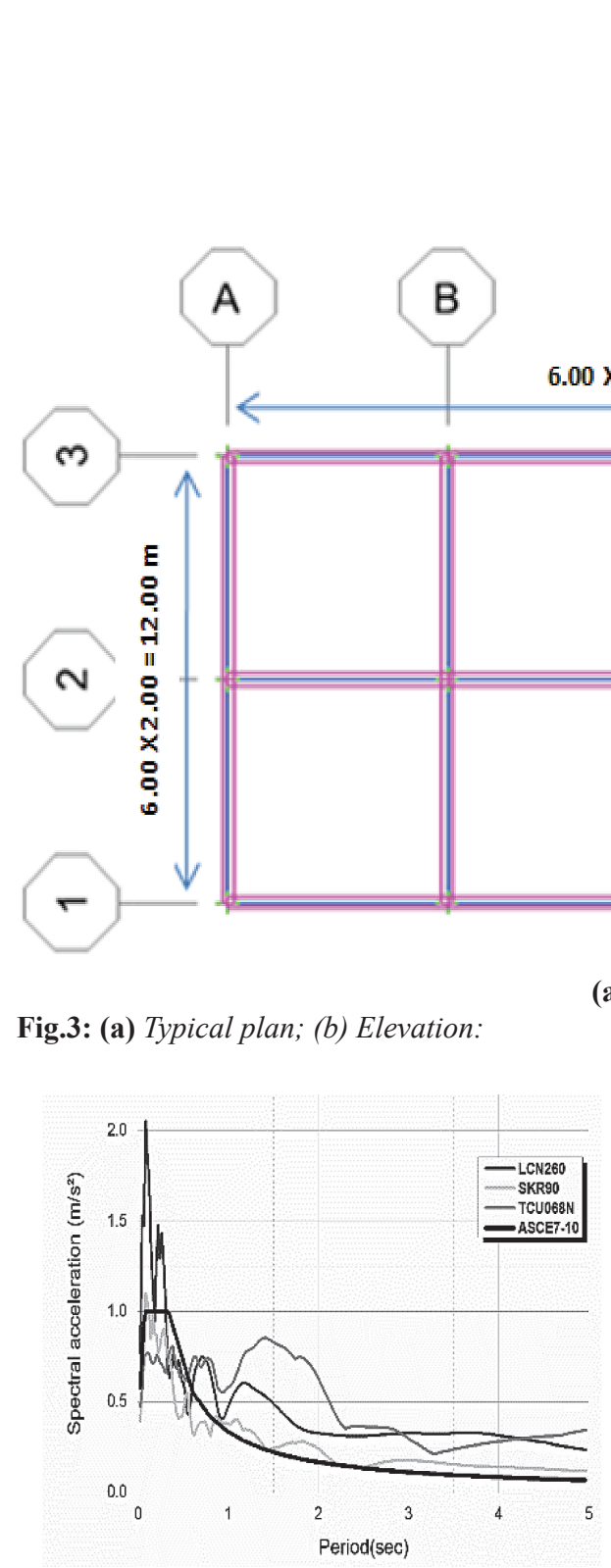

(a)

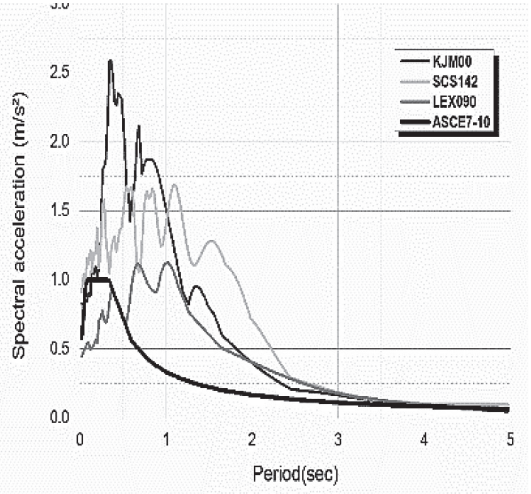

(b)

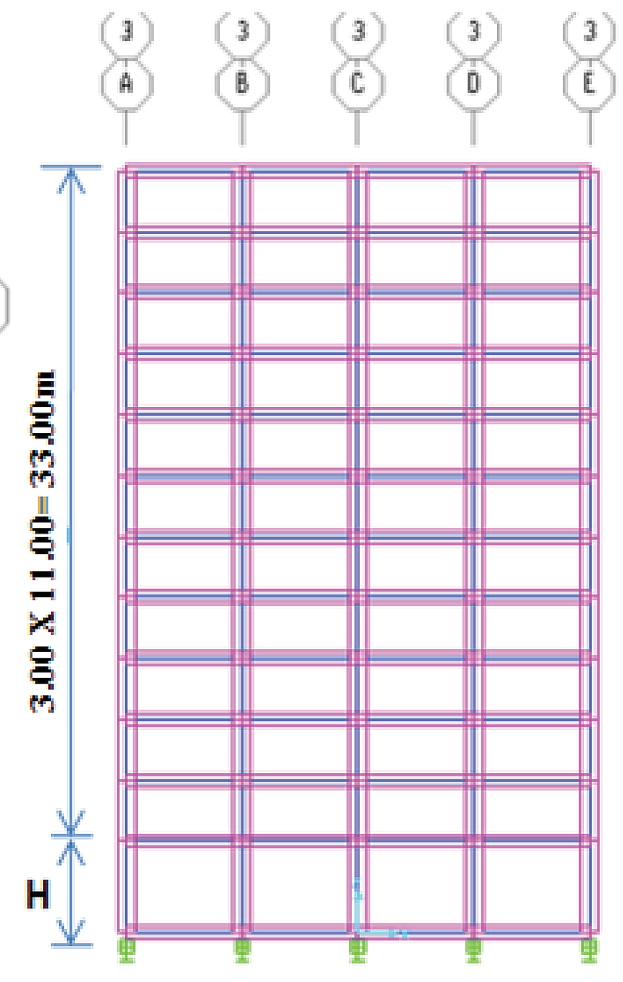

(b)

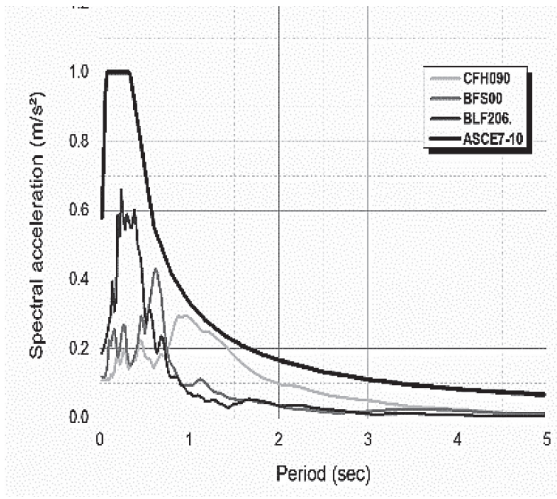

(c)

Fig.4: (ASCE7-10) design spectrum and response spectra of (a) original fling-step records, (b) original forward-directivity records and, (c) original Farr -field records. 


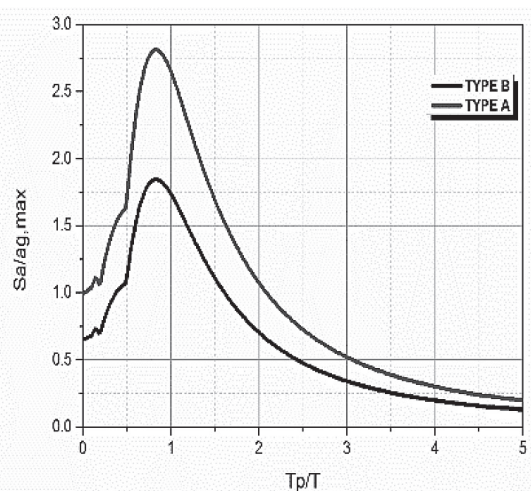

(a)

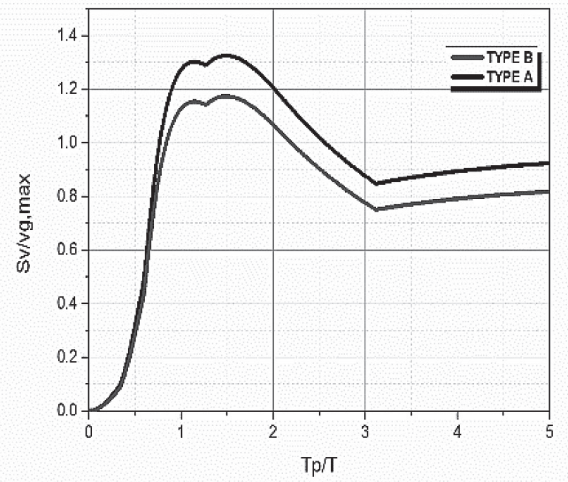

(b)

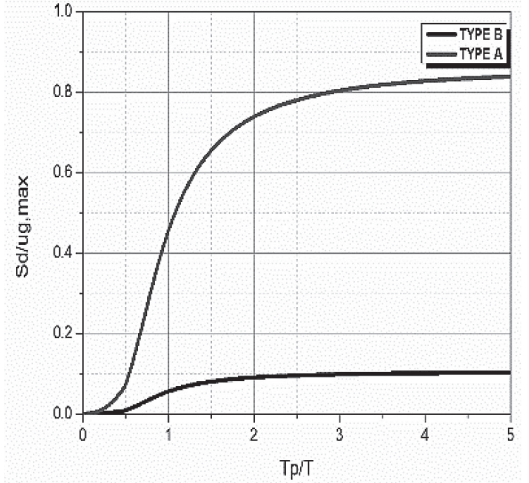

(c)

Fig.5: Five percent damped normalized (a) acceleration, (b) velocity, and (c) displacement response (elastic) spectra for idealized sinusoidal pulses. (Type A: fling-step; Type B: forward-directivity.)
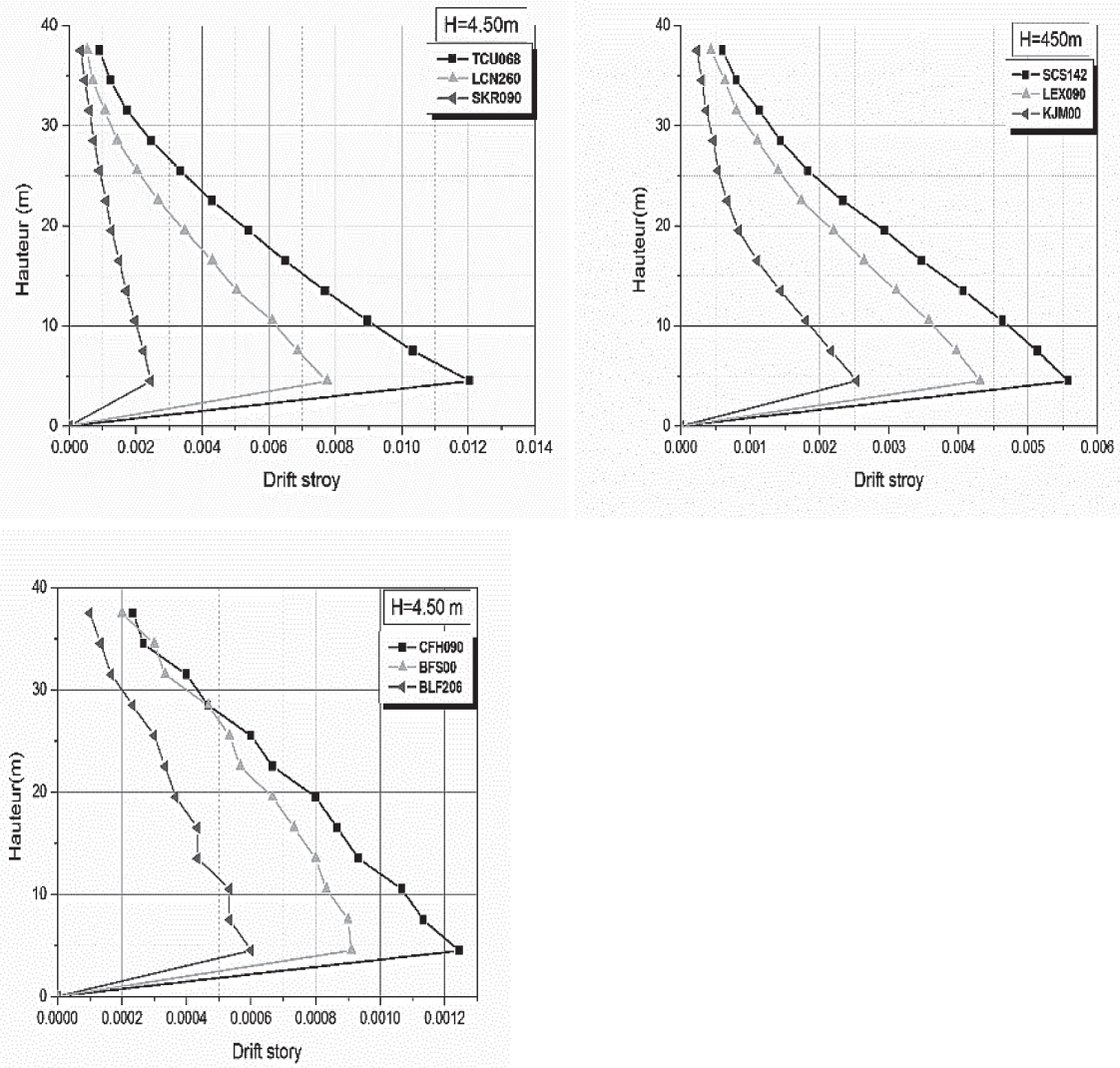

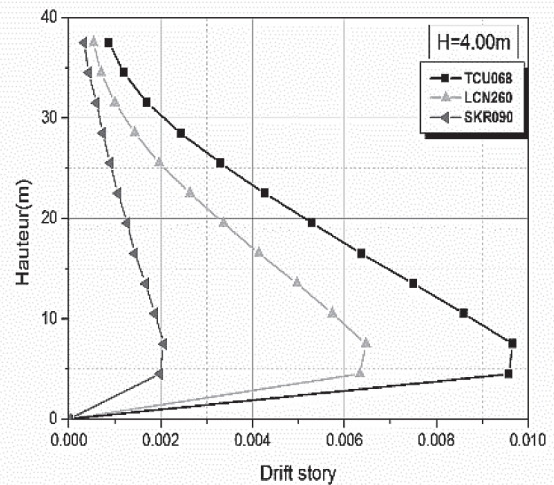

(a)

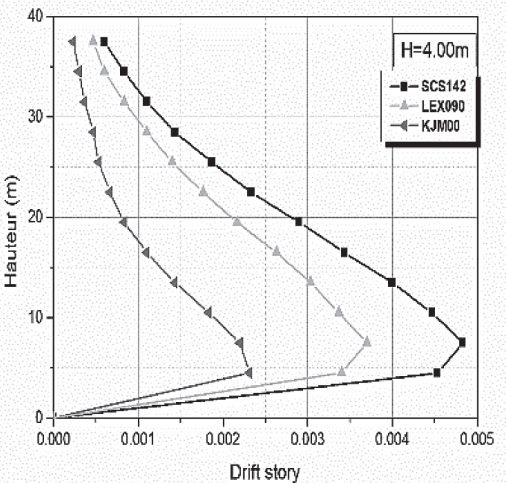

(b)

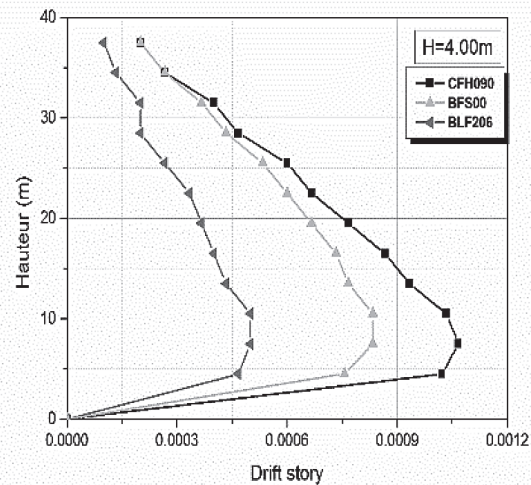

(c) 

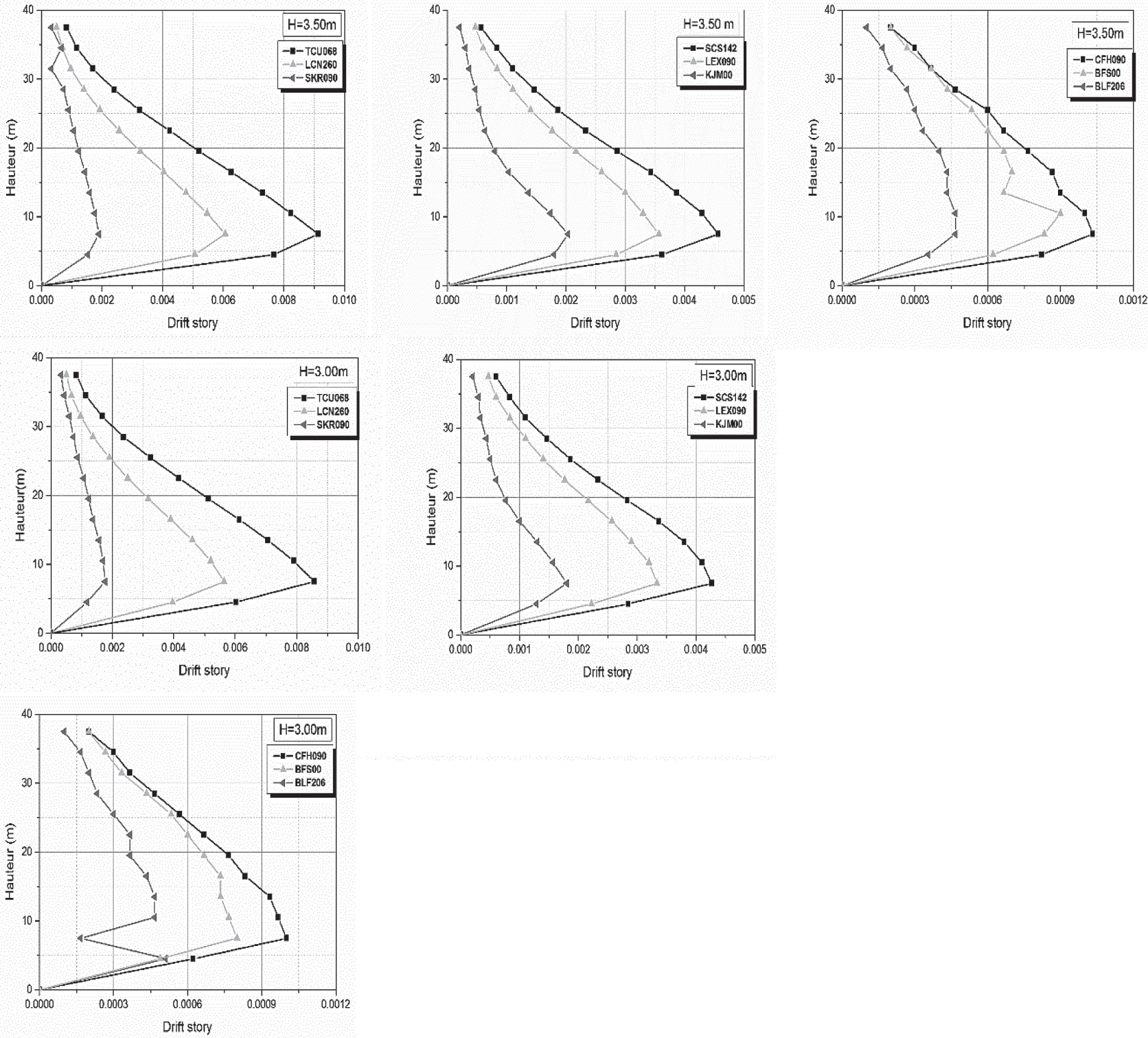

(a)

(b)

(c)

Fig.6: Maximum inter-story drift for base isolated building subjected to:, (a) near-fault motions with fling, (b) near-fault motions with forward directivity, (c) far-fault motions

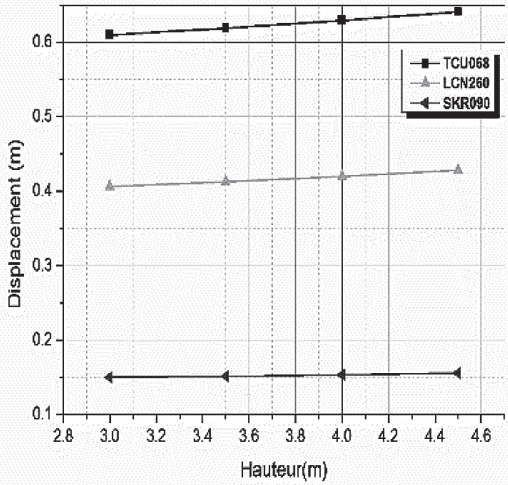

(a)

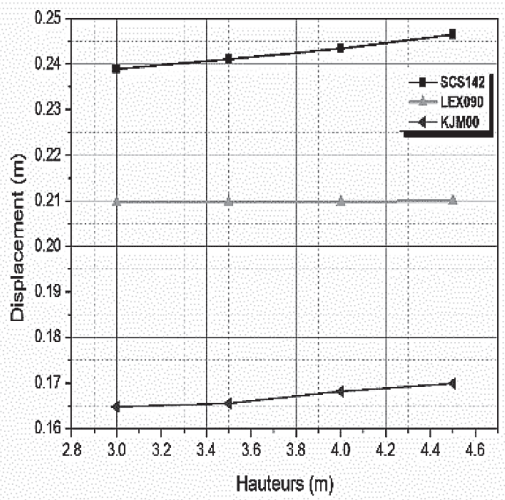

(b)

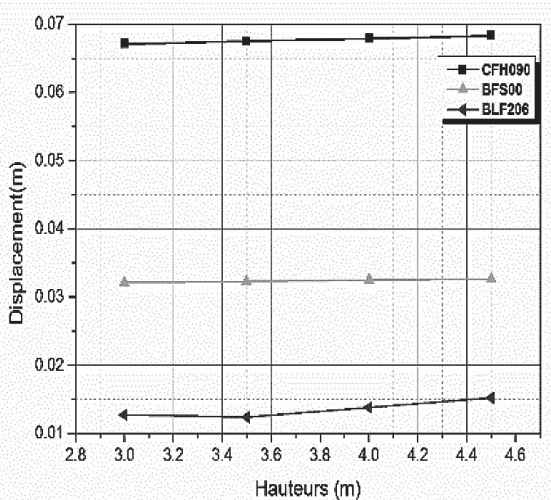

(c)

Fig.7: Variation of maximum first story displacement for base isolated building subjected to (a) near-fault motions with fling, (b) near-fault motions with forward directivity, (c) far-fault motions 

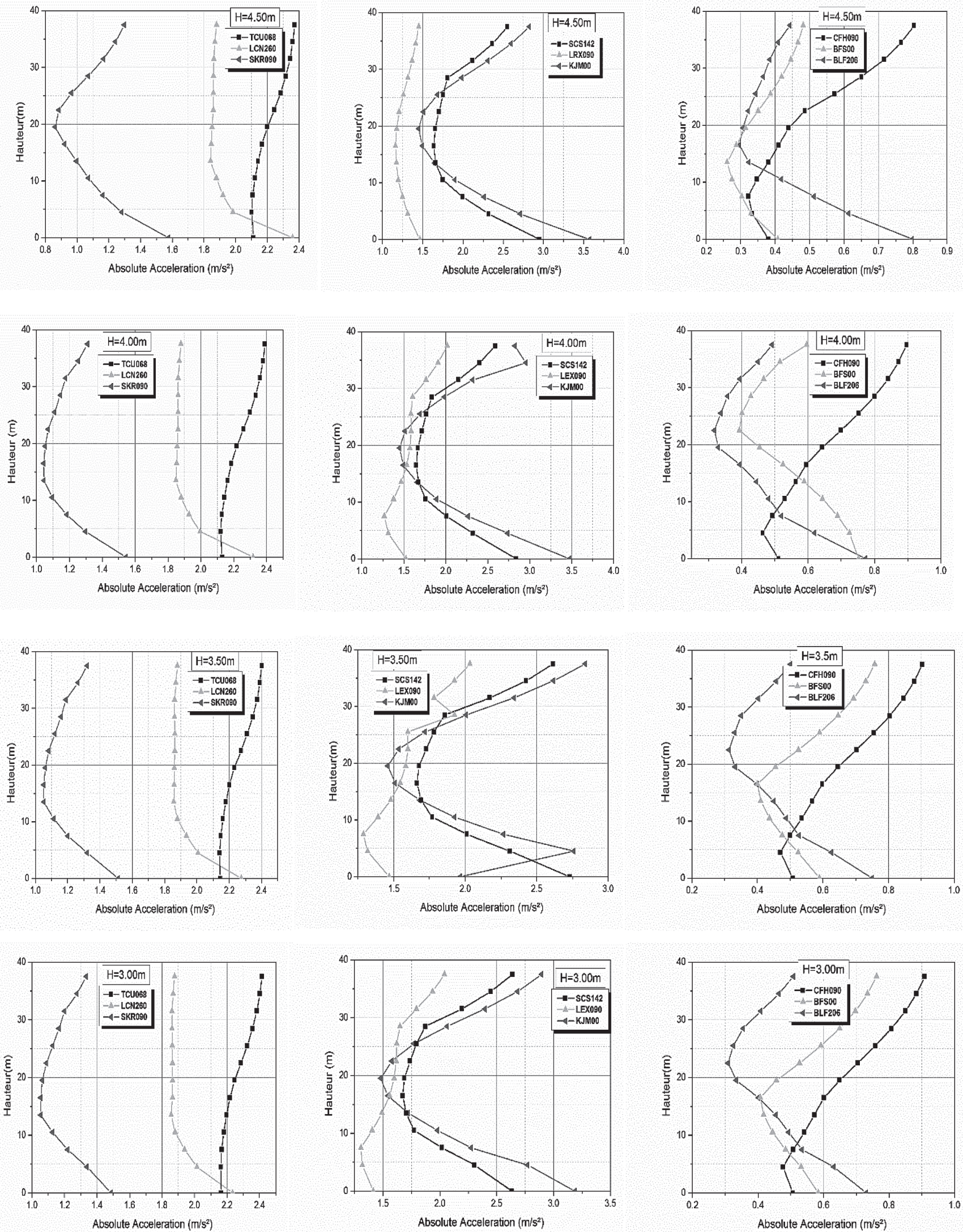

(a)

(b)

(c)

Fig.8: Maximum absolute acceleration for base isolated building subjected to:, (a) near-fault motions with fling, (b) near-fault motions with forward directivity, (c) far-fault motions 

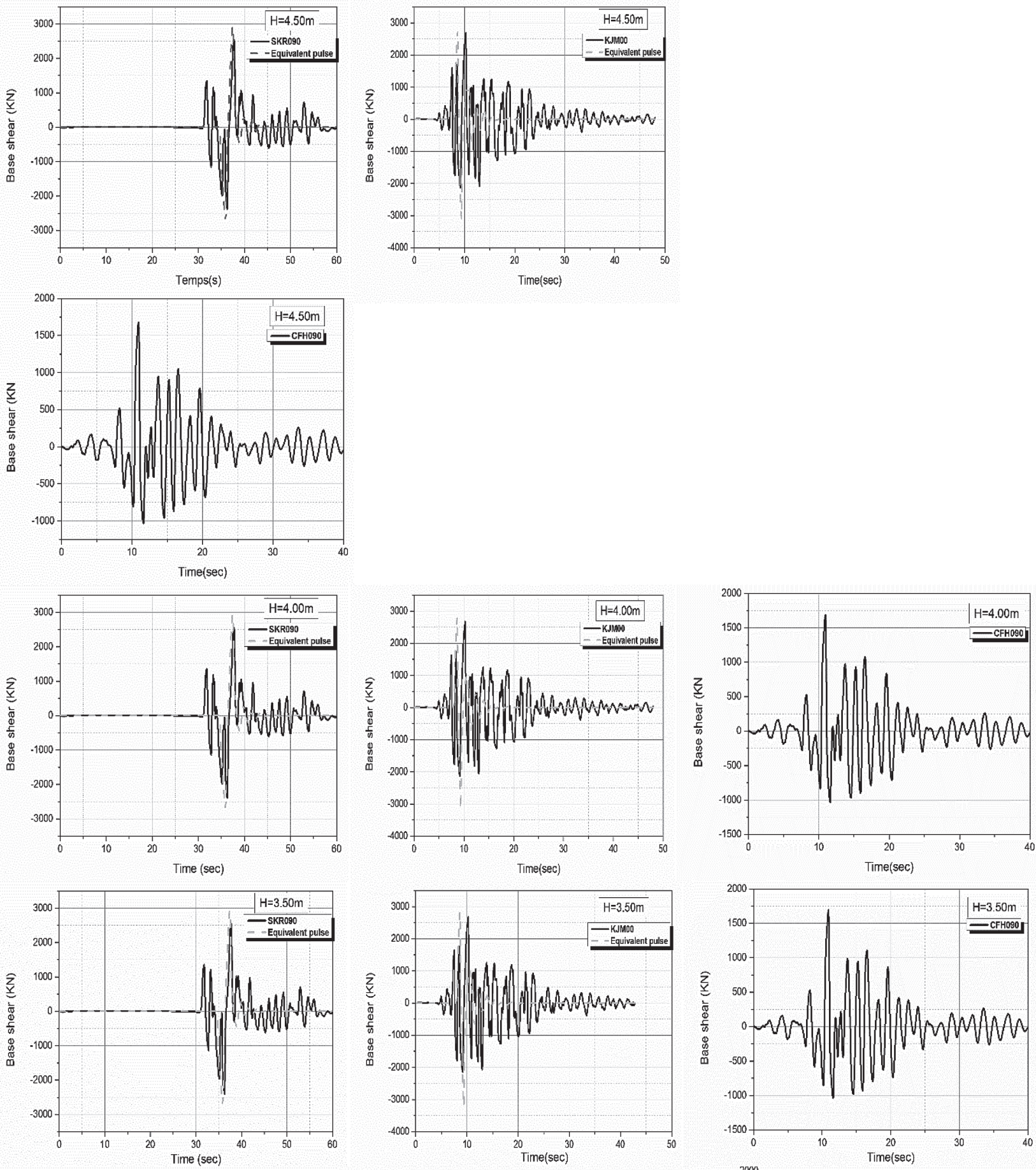

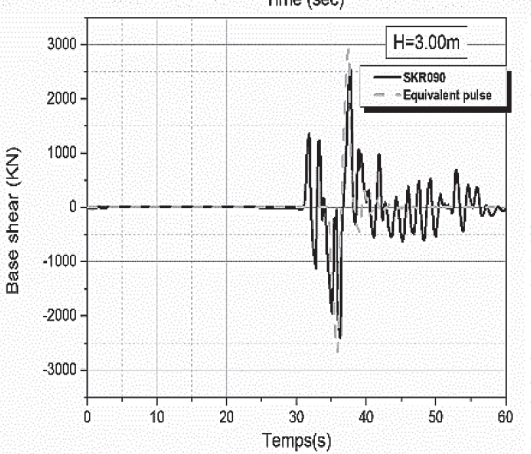

(a)

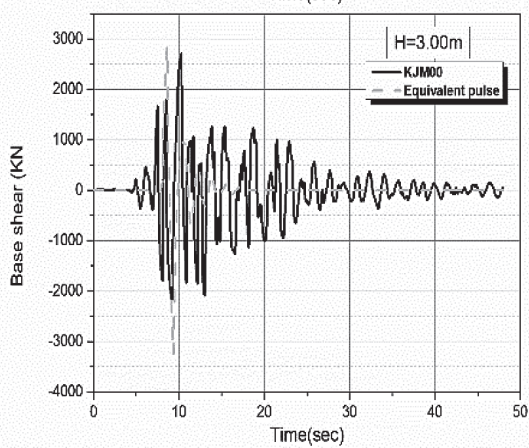

(b)

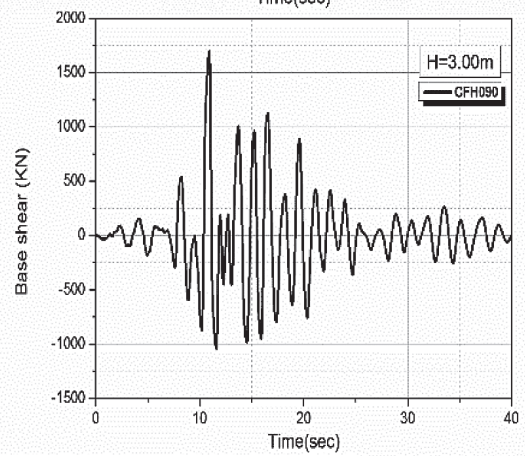

(c)

Fig.9: Base shear force for base isolated building subjected to:, (a) near-fault motions with fling, (b) near-fault motions with forward directivity, (c) far-fault motions 


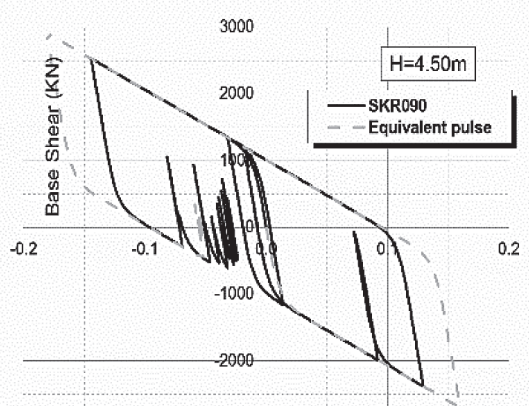

-3000 Displacement $(\mathrm{m})$

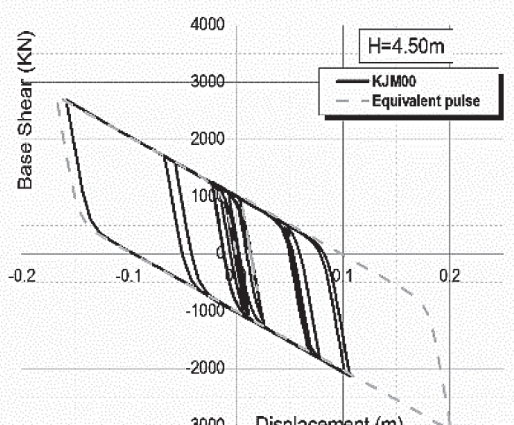

3000 Displacement $(\mathrm{m})$
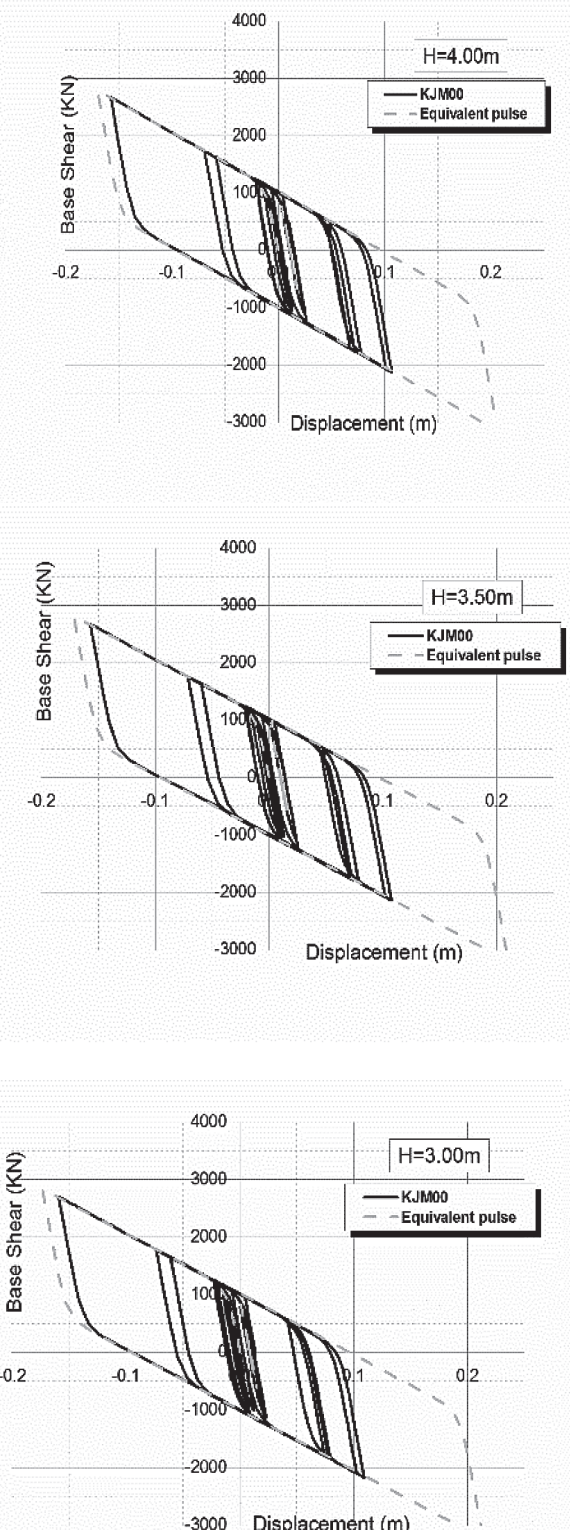

(b)
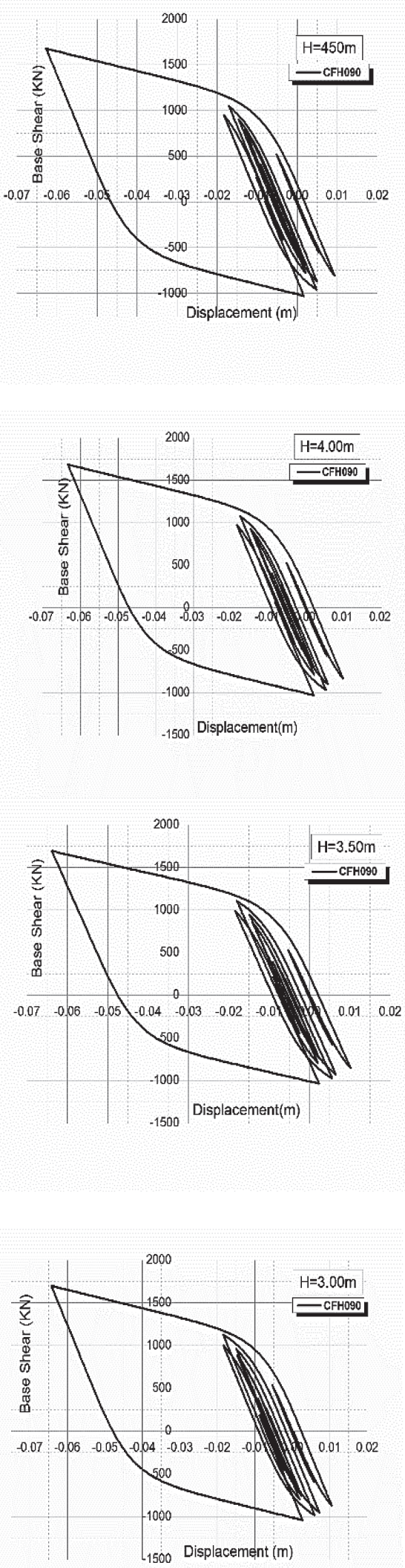

(c)

(a)

Fig. 10: Hysteretic responses for base isolated building subjected to:, (a) near-fault motions with fling, (b) near-fault motions with forward directivity, (c) far-fault motions 

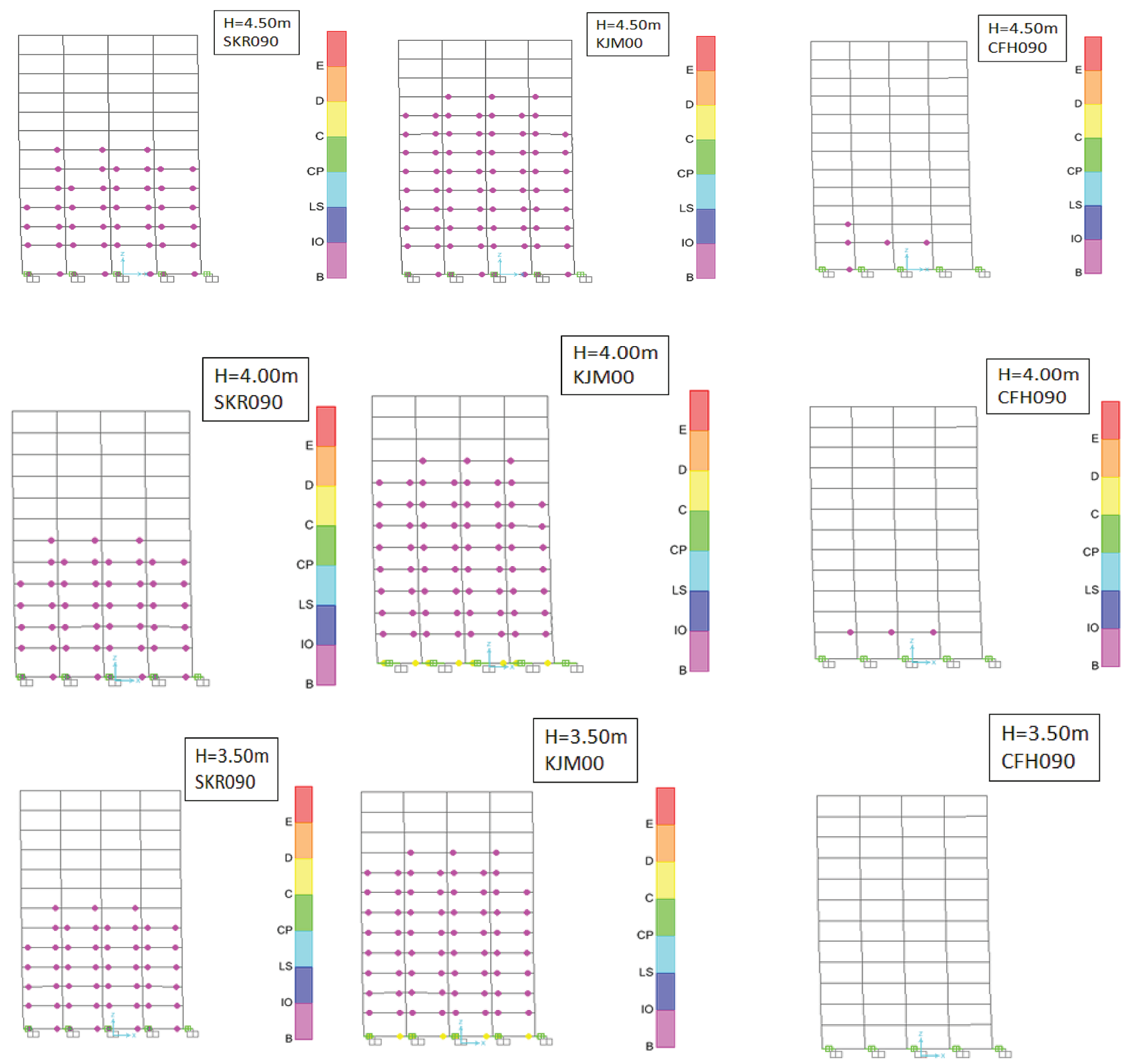

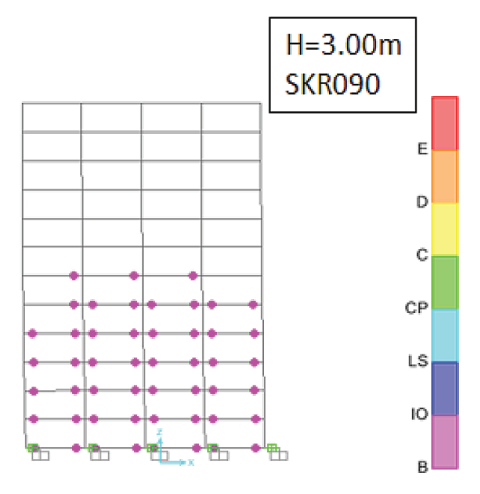

(a)

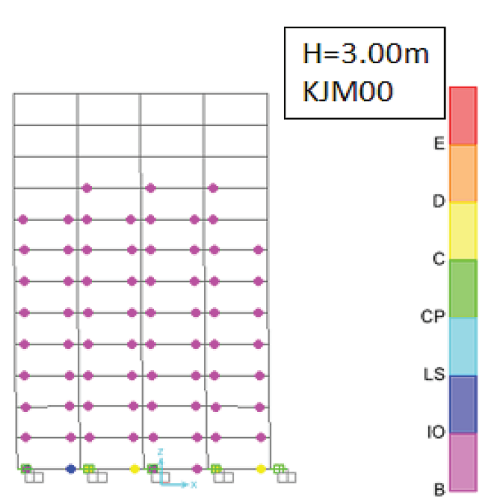

(b)

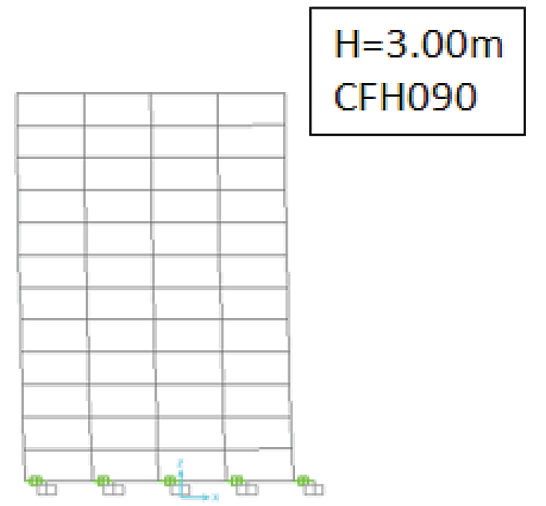

(c)

Fig.11: Plastic hinge locations for the 12-story structure subjected to (a) near-fault motion with fling step (SKR090), (b) near-fault motion with forward directivity (KJMA00), (c) far-fault motion (CFH090) 
Tab 1. Ground motion database

\begin{tabular}{|c|c|c|c|c|c|c|c|c|c|c|c|}
\hline $\mathrm{N}^{\circ}$ & Year & Earthquake & $M_{W}$ & Mech $^{\mathrm{a}}$ & Recording station & $\begin{array}{l}\text { Dist. } \\
(\mathrm{km})\end{array}$ & $\begin{array}{c}\text { Site } \\
\text { Classc }\end{array}$ & Comp. & $\begin{array}{c}\text { PGA } \\
(g)\end{array}$ & $\begin{array}{l}\mathrm{PGV} \\
(\mathrm{cm} / \mathrm{s})\end{array}$ & PGD $(\mathrm{cm})$ \\
\hline \multicolumn{12}{|c|}{ Near-fault ground motions with forward directivity } \\
\hline 1 & 1995 & Kobe & 6.9 & SS & JMA(KJM) & 0.6 & $\mathrm{C}$ & 000 & 0.821 & 81.276 & 17.827 \\
\hline 2 & 1989 & Loma Prieta & 7.0 & OB & Lexington Dam (LEX) & 6.3 & $\mathrm{C}$ & 090 & 0.433 & 86.245 & 30.044 \\
\hline 3 & 1994 & Northridge & 6.7 & TH & Sylmar Converter Station (SCS) & 5.4 & $\mathrm{D}$ & 142 & 0.897 & 102.22 & 45.519 \\
\hline \multicolumn{12}{|c|}{ Near-fault ground motions with fling } \\
\hline 1 & 1999 & Kocaeli & 7.4 & SS & Sakarya (SKR) & 3.2 & $\mathrm{C}$ & 90 & 0.376 & 79.196 & 74.209 \\
\hline 2 & 1992 & Landers & 7.3 & SS & Lucerne (LCN) & 2.2 & B & 260 & 0.727 & 146.49 & 262.80 \\
\hline 3 & 1999 & Chi-Chi & 7.6 & $\mathrm{TH}$ & TCU068 & 0.32 & $\mathrm{D}$ & NS & 0.462 & 261.46 & 477.83 \\
\hline \multicolumn{12}{|c|}{ Far-Fault Recordings } \\
\hline 1 & 1992 & Landers & 7.3 & SS & Boron - Fire Stn. (BFS) & 89.69 & $\mathrm{D}$ & 00 & 0.117 & 9.928 & 7.110 \\
\hline 2 & 1989 & Loma Prieta & 7.0 & OB & Cliff House (CFH) & 78.68 & $\mathrm{C}$ & 90 & 0.108 & 19.625 & 7.170 \\
\hline 3 & 1994 & Northridge & 6.7 & TH & Montebello(BLF) & 44.2 & $\mathrm{D}$ & 206 & 0.179 & 9.418 & 2.062 \\
\hline
\end{tabular}

${ }^{(a)}$ Faulting Mechanism = TH: Thrust; REV: Reverse; SS: Strike-slip; OB: Oblique

Data Source: PEER (http://peer.berkeley.edu/smcat) 